\title{
PENGARUH CLAMPING FRAME KAYU MERANTI DAN ASTM A36 PADA FRICTION SPOT JOINING AL 1100 DAN PVC
}

\author{
Rudianto Raharjo \\ Lektor(Dosen) \\ Universitas Brawijaya \\ Jurusan Teknik Mesin \\ rudiantoraharjo@ub.ac.id \\ Nurkholis Hamidi \\ Lektor Kepala(Dosen) \\ Universitas Brawijaya \\ Jurusan Teknik Mesin \\ hamidy@ub.ac.id
Teguh Dwi Widodo
Lektor (Dosen)
Universitas Brawijaya
Jurusan Teknik Mesin
widodoteguhdwi@ub.ac.id \\ Redi Bintarto \\ Asisten Ahli(Dosen) \\ Universitas Brawijaya \\ Jurusan Teknik Mesin \\ redibintarto@ub.ac.id

\section{Endi Habibulfalah \\ Mahasiswa S1 Universitas Brawijaya Jurusan Teknik Mesin}

In this paper, the effect of welding parameters on the shear strength of Al-PVC hybrid structures was discussed. This Research developed welding parameters in the form of Plunge Depth, heating time, and clamping frame materials. By these different parameters would result in different shear strength of welded materials. Following optimization of the process, a detailed comparison of the properties and microstructures of two different materials (meranti wood and ASTM A36 Steel) would affect to different values of thermal conductivity. The Aluminum used was Al 1100, which was welded by using a friction stir spot welding method with Polyvinyl Chloride (PVC). In this study, by the different heating times, the shear test was carried out with the ASTM D3163 standard. In this study, it was found that the maximum temperature of Aluminum occurs during the $2^{\text {nd }}$ second of the welding process and then decreased in the $5^{\text {th }}$ second until $60^{\text {th }}$ second. However, the optimum shear strength found at $20^{\text {th }}$ second. Following heat transfer and degradation materials, the $2 \mathrm{~mm}$ plunge depth has a higher temperature and higher shear strength than 1,5mm plunge depth. Differences in the response of the two depth were attributed to the difference in mechanical interlocking. This study found that the ASTM A36 clamping frame maximum shear load of $182.4 \mathrm{~N}$ is higher than meranti wood frame of $125.5 \mathrm{~N}$. Differences in these value are attributed to the differences of the thermal conductivity, which meranti wood had a lower thermal conductivity than ASTM A36. These have findings significant implications for the commercial application of welding hybrid structures. The best way to take advantage of the benefit of AL-PVC Structure Hybrid for friction stir spot welding would appear to be 20 second heating time, $2 \mathrm{~mm}$ plunge depth with ASTM clamping frame.

Keywords: Clamping Frame, Meranti, Friction Spot Joining.

\section{PENDAHULUAN}

Dengan meningkatnya kebutuhan akan material lightweight, peningkatan fungsi dari struktur hybrid menghasilkan demand yang tinggi pada beberapa sektor produksi diantaranya automotif, aerospace, dan biomedic. Diantara kendala utama yang biasanya terdapat distruktur hybrid melibatkan penyambungan dari dua material yang berbeda jauh dari segi mekanikal, physical, dan thermal properties. Pada struktur ini material yang mulai banyak digunakan adalah material dari joining antara metal dan polimer. Pada proses joining biasa yaitu adhesive bonding dan mechanical joining terdapat beberapa kendala. Dimana mechanical joining biasanya melibatkan struktur yang akan dibor lalu dipasang mur dan baut sehingga meningkatkan berat struktur dan biaya 
joining.[1-3]

Untuk melakukan proses joining dapat dilakukan dengan beberapa cara seperti adhesive bonding dan mechanical fastening. Adhesive bonding merekatkan antara dua permukaan dengan menggunakan zat adhesive. Dalam pelaksanaannya, adhesive bonding memerlukan waktu curing yang lama, sehingga pengerjaan menjadi tidak efisien dan efektif, selain itu, zat adhesive pada adhesive bonding tidak tahan suhu tinggi, sehingga joining dengan metode ini akan membatasi pada penggunannya.[4-6]

Pada umumnya jika penyambungan menggunakan mechanical joining terdapat dua masalah utama. Yaitu waktu yang diperlukan untuk membuat lubang pada sheet dan terdapat adanya konsentrasi tegangan pada sambungan yang mana mempengaruhi property mekanikal dari struktur. Selain itu, dengan menggunakan mechanical joining akan menambah massa dari kedua benda yang digabungkan. [7-8]

Untuk dapat menghadapi keterbatasan ini beberapa proses yang sedang dikembangkan untuk memproduksi struktur hybrid pada metal dan polymer termasuk Friction Stir welding,Laser Assisted Joining (LAJ), friction riveting, friction based stacking. Salah satunya dengan metode friction assisted joining (FAJ) pada metal dan polimer. Yang mana memiliki solusi untuk mengatasi masalah diatas. Dengan proses FAJ artinya tidak ada waktu terbuang untuk membuat lubang pada sheet. Serta dikarenakan prosesnya tidak mengunakan bor sehingga pada struktur hanya sedikit terjadi konsentrasi tegangan. Jika membandingkan proses Laser Assisted Joining dan Friction assisted joining, kekuatan dari joint sangat dipengaruhi oleh temperatur yang dihasilkan oleh proses las. Tetapi belum ada studi yang mengevaluasi bagaimana konduktifitas panas terhadap frame penjepit mempengaruhi proses joining dan kualitas dari las-lasan. [9-14]

Pada penelitian ini, sheet metal terbuat dari Al 1100 Aluminium alloy yang mana akan disambungkan oleh Polyvinyl Cholride (PVC) dengan proses friction assisted joining. Material tersebut ditahan oleh frame penjepit agar tidak bergerak selama proses yang terjadi. Dua material berbeda akan digunakan sebagai frame penjepit yaitu kayu meranti dan ASTM A36 carbon steel. Material ini digunakan karena memiliki perbedaan konduktivitas thermal yang tinggi, waktu pemanasan juga akan divariasikan. Metode penyambungan yang akan digunakan adalah Friction Stir Spot Welding dimana saat penyambungan, alumunium akan mendapatkan panas sehingga temperatur pada alumunium tinggi, PVC akan meleleh sehingga akan terjadi sifat adhesi pada Alumunium dan PVC, dan nub juga akan membantu peningkatan kekuatan sambungan.

\section{METODE DAN BAHAN}

Metode yang digunakan dalam penelitian ini adalah metode eksperimental nyata ( true experimental research). Kajian literatur dari berbagai sumber baik dari buku, jurnal yang ada di perpustakaan maupun internet juga digunakan untuk menambah informasi yang diperlukan. Persiapan bahan dalam penelitian yaitu Peralatan yang digunakan pada penelitian ditunjukan pada Gambar 1.

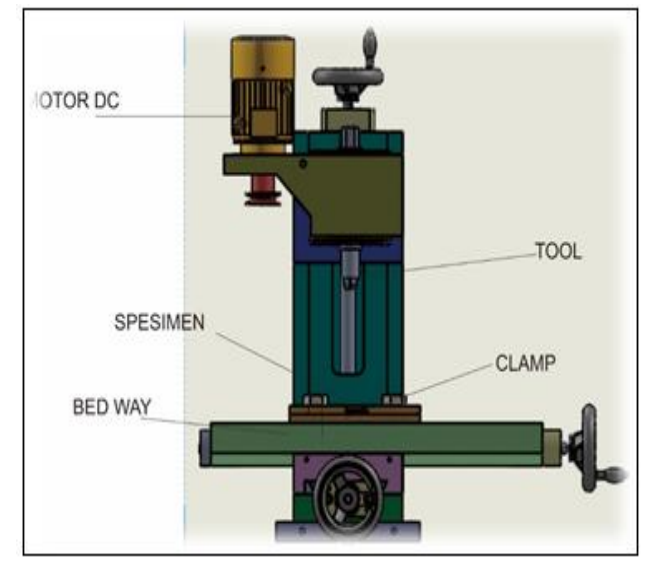

\section{Gambar 1: Skema Penelitian}

Proses pembuatan spesimen menggunakan metode friction spot welding. Terlebih dahulu spesimen Al disusun secara lap joint dan dijepit oleh clamping frame seperti yang ditunjukan pada Gambar 2 dan Gambar 3. [15] 


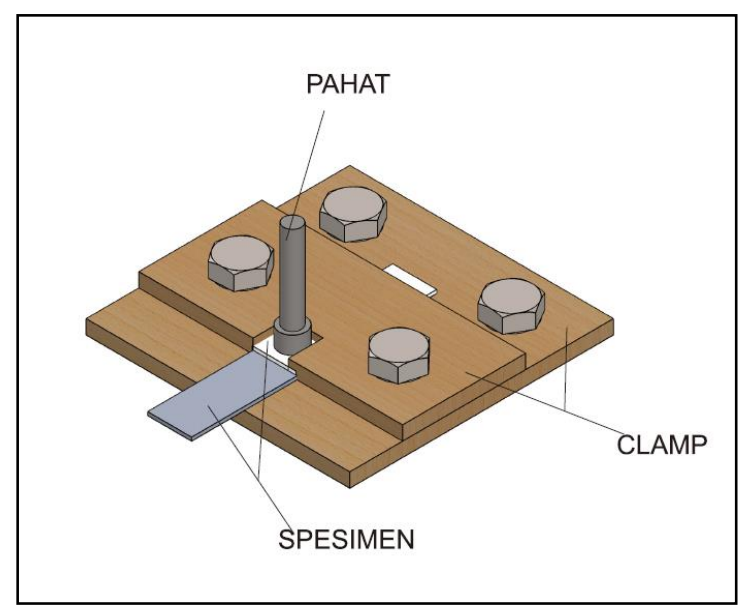

Gambar 2: Skema setup clamping frame

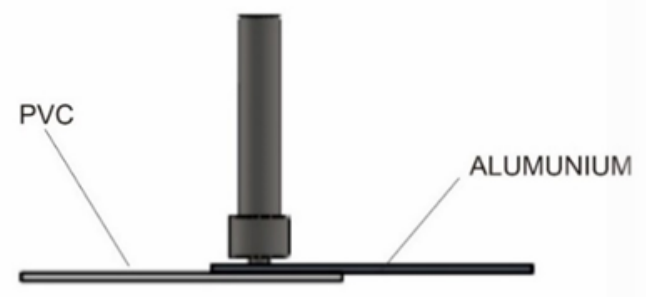

Gambar 3: Skema setup spesimen sebelum dilakukan proses friction stir welding

Lalu dilakukan proses friction spot weld dengan variabel terkontrol berupa Spindle speed : $4700 \mathrm{rpm}$, diameter pin pahat : $5 \mathrm{~mm}$, diameter shoulder pahat : $15 \mathrm{~mm}$. Lalu variabel bebas yang dilakukan dalam penelitian ini yaitu : material clamping frame berupa ASTM A36 dan kayu meranti, Heating time selama $10 \mathrm{~s}, 20 \mathrm{~s}, 30 \mathrm{~s}$ dan $60 \mathrm{~s}$, dan plunge depth sebesar 1,5mm dan $2 \mathrm{~mm} .[16]$

\subsection{Uji Geser}

Sebelum dilakukan pengujian geser spesimen ini dibentuk sesuai standart ASTM D 1002 (Standard test method for determining strength of adhesively bonded rigid plastic lap shear-joint in shear by tension loading) seperti pada Gambar 4 berikut.[17]

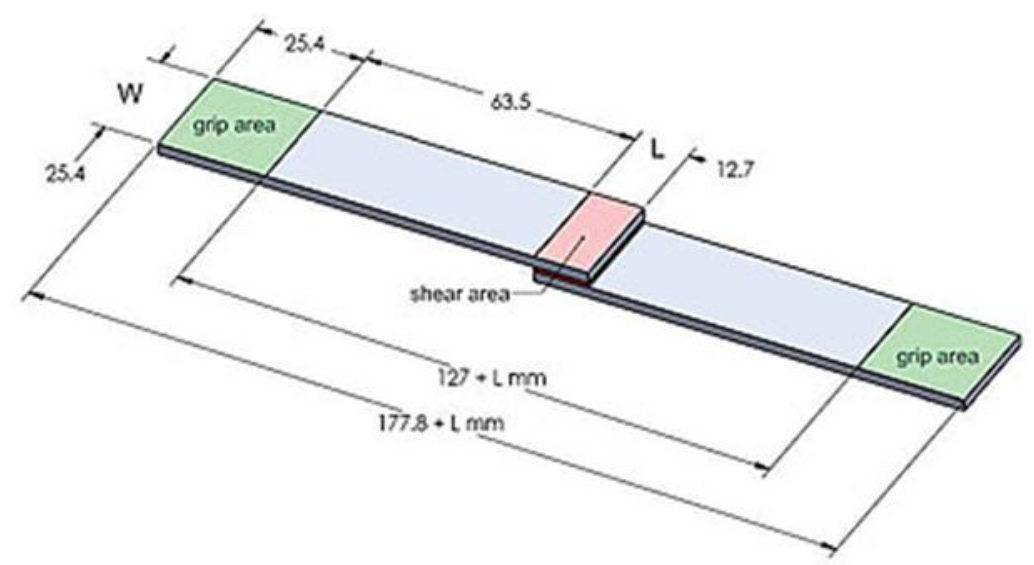

Gambar 4: Spesimen Uji geser secara lap joint 


\section{HASIL DAN DISKUSI}

Pada bagian ini harus ditampilkan seluruh data yang diperoleh dengan informasi yang cukup bagaimana data tersebut diperoleh. Analisa statistik boleh disampaikan jika dianggap perlu, atau cukup ditampilkan dalam grafik disertai standar deviasi serta error bars dan penjelasan arti signifikansi secara statistik dari standar deviasi maupun error bars dalam grafik tersebut.

Material clamping frame, heating time dan plunge depth dapat mempengaruhi kekuatan geser dari sambungan antara alumunium dengan PVC saat penyambungan menggunakan metode friction stir spot welding, grafik dari hubungan ini ditampilkan pada Gambar 5.

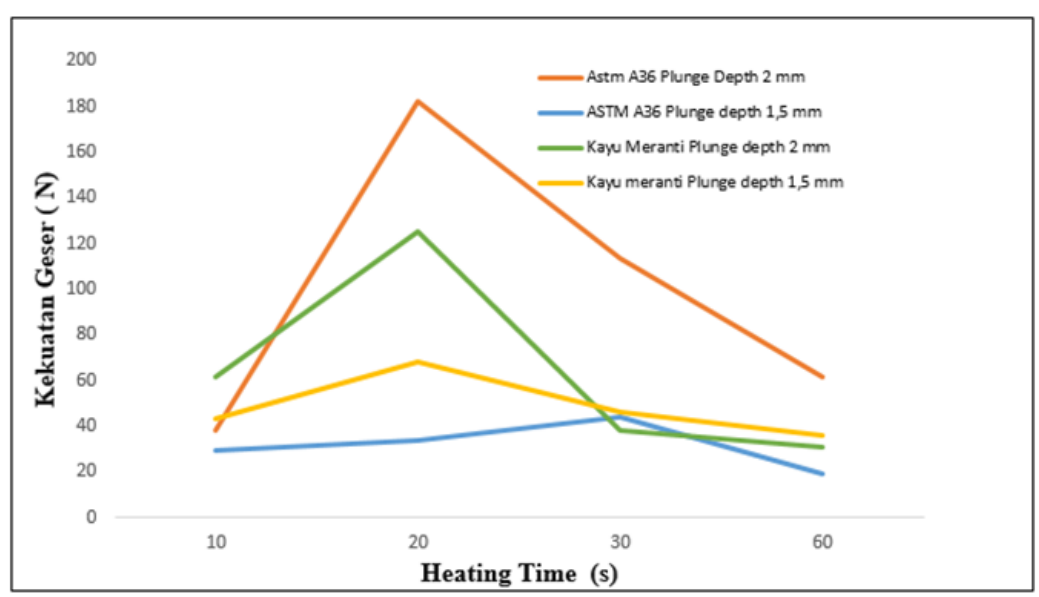

Gambar 5. Kekuatan geser sambungan Alumunium PVC

Gambar 5 menjelaskan tentang hubungan heating time dengan kekuatan geser pada sambungan AlumuniumPVC menggunakan clamping frame ASTM A36 dan Kayu Meranti, dimana sumbu x menjelaskan tentang heating time sedangkan sumbu y menjelaskan tentang kekuatan geser. Dari Gambar 5 diatas, dapat dilihat bahwa kecenderungan dari grafik adalah menurun, dimana prosesnya adalah pada detik 10 menuju detik 20 terjadi kenaikan nilai kekuatan geser, hal ini disebabkan karena degradasi yang terjadi pada PVC belum banyak sehingga belum merusak PVC itu sendiri, selain itu panas yang masuk ke alumunium optimum dalam melunakan pvc.

\subsection{Pengaruh temperatur spesimen}

PVC yang melunak dapat menyebabkan terjadinya mechanical interlocking. Pada detik 20 sampai ke detik 60, kekuatan gesernya melemah dikarenakan panas yang masuk ke alumunium melebihi panas optimum sehingga menghasilkan degradasi pada PVC yang akhirnya melemahkan sambungan.

Pada grafik diatas, menjelaskan tentang perbandingan kekuatasn geser antara plunge depth 1,5 mm dan $2 \mathrm{~mm}$, grafik cenderung menurun, namun pada prosesnya dapat dilihat bahwa kekuatan geser terbesar dimiliki oleh variasi plunge depth $2 \mathrm{~mm}$, hal ini dikarenakan, panas yang masuk pada alumunium ada pada titik yang lebih optimal sehingga degradasi yang terbentuk pada PVC belum terlalu merusak kekuatan sambungan serta panas yang masuk ke alumunium dapat melunakan PVC dengan lebih optimal dibandingkan dengan variasi plunge depth 1,5 mm sehingga PVC yang melunak lebih banyak yang akan menghasilkan mechanical interlocking. Selain itu pembentukan nub juga akan lebih dalam jika menggunakan plunge depth 2 mm sehingga menyebabkan kekuatan geser yang lebih baik.

Kekuatan geser pada spesimen yang tertinggi ada pada spesimen yang menggunakan clamping frame ASTM A36 yaitu dengan nilai kekuatan geser sebesar 182,4 $\mathrm{N}$ pada variasi heating time 20 detik, namun temperatur yang tertinggi ada pada spesimen dengan menggunakan clamping frame kayu meranti, pada kayu meranti terjadi degradasi thermal yang lebih banyak dari clamping frame ASTM A36 pada detik yang sama, hal inilah yang membuat kekuatan geser pada spesimen dengan clamping frame kayu lebih rendah dari clamping frame ASTM A36. Untuk mencapai titik optimum kekuatan geser pada tiap-tiap clamping frame, dibutuhkan penelitian yang lebih mendetail pada tiap-tiap jenis clamping frame dan heating time.

Heating time, material clamping frame, dan plunge depth dapat mempengaruhi temperatur pada spesimen alumunium dan PVC saat penyambungan menggunakan metode friction stir spot welding, grafik dari hubungan ini ditampilkan pada Gambar 6. 


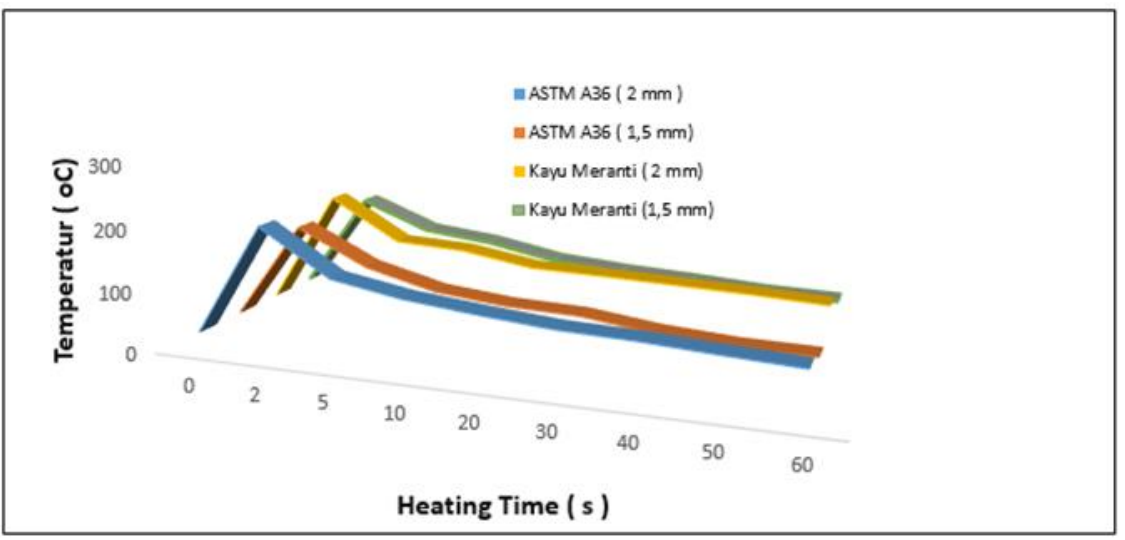

Gambar 6: Temperatur spesimen saat pengelasan

Gambar 6 menjelaskan tentang hubungan heating time dengan temperatur pada spesimen alumunium saat proses pengelasan dengan menggunakan dua clamping frame yang berbeda yaitu Baja ASTM A36 dan Kayu Meranti, serta dua variasi plunge depth $1,5 \mathrm{~mm}$ dan $2 \mathrm{~mm}$,sumbu $\mathrm{x}$ menjelaskan tentang variasi heating time yang digunakan sementara sumbu y menjelaskan tentang temperatur yang dicapai.

Dari grafik diatas, dapat dilihat bahwa kecenderungan dari grafik adalah menurun, namun pada dua detik awal terjadi temperature jump yang diakibatkan karena pin beserta shoulder sudah memakan alumunium pada kedalaman yang ditentukan untuk pertama kali, dari grafik diatas terlihat bahwa sambungan dengan menggunakan plunge depth $2 \mathrm{~mm}$ menghasilkan suhu yang lebih tinggi dibandingkan plunge depth 1,5 $\mathrm{mm}$.

Temperatur spesimen lebih tinggi jika menggunakan clamping frame kayu meranti, hal ini dikarenakan konduktivitas thermal kayu meranti lebih kecil yaitu $0,014 \mathrm{~W} / \mathrm{m}$. K dibandingkan dengan konduktivitas thermal baja ASTM A36 yaitu $50 \mathrm{~W} / \mathrm{m} . \mathrm{K}$, sehingga kalor yang masuk ke alumunium akan lebih tinggi.

karena kalor tidak banyak yang terkonduksi ke clamping frame, hal ini berkebalikan dengan material clamping frame ASTM A36 dimana memiliki konduktivitas yang lebih tinggi sehingga kalor banyak terkonduksi ke material clamping frame sehingga menurunkan temperatur spesimen.

Turunnya temperatur saat semakin lamanya heating time, disebabkan karena pahat sudah tidak ada pergerakan vertikal saat dilakukan pengukuran, dan semakin lama pengelasan dilakukan, pin dan shoulder semakin tidak menggesek alumunium dikarenakan massa alumunium sudah berpindah akibat pergerakan dari pin dan shoulder itu sendiri dalam rangka pembentukan $n u b$, serta melunakkan PVC sehingga pin dan shoulder hanya menggesek sisa dari massa alumunium yang ada pada titik pengelasan, hal ini menyebabkan penurunan temperatur pada specimen.

\subsection{Analisis Temperatur Clamping frame}

Heating time, dan plunge depth dapat mempengaruhi temperatur pada material clmping frame pada proses penyambungan alumunium dan PVC menggunakan metode friction stir spot welding, grafik dari hubungan ini ditampilkan pada Gambar 7.

Gambar 7 menjelaskan tentang grafik hubungan temperatur dengan heating time pada clamping frame, dimana clamping frame yang digunakan adalah ASTM A36 dan kayu meranti. Masing-masing menggunakan pahat dengan plunge depth $1,5 \mathrm{~mm}$ dan $2 \mathrm{~mm}$. Sumbu x menjelaskan tentang heating time sementara sumbu y menjelaskan tentang temperatur.

Pada grafik diatas dapat dilihat bahwa temperatur yang ada pada clamping frame ASTM A36 lebih tinggi dibandingkan dengan temperatur pada clamping frame kayu meranti, grafik cenderung naik dari heating time awal yaitu di detik 10 sampai detik akhir yaitu detik 60 pada kedua clamping frame, hal ini terjadi karena penambahan kalor yang dilakukan secara terus menerus selama waktu pemanasan. Penyebab dari tingginya temperatur clamping frame ASTM A36 dibandingkan dengan clamping frame kayu meranti adalah nilai konduktivitas thermal dari ASTM A36 lebih tinggi dibandingkan dengan kayu meranti, sehingga panas yang masuk ke spesimen terkonduksikan lebih baik oleh clamping frame ASTM A36, hal ini membuat temperatur pada specimen. 


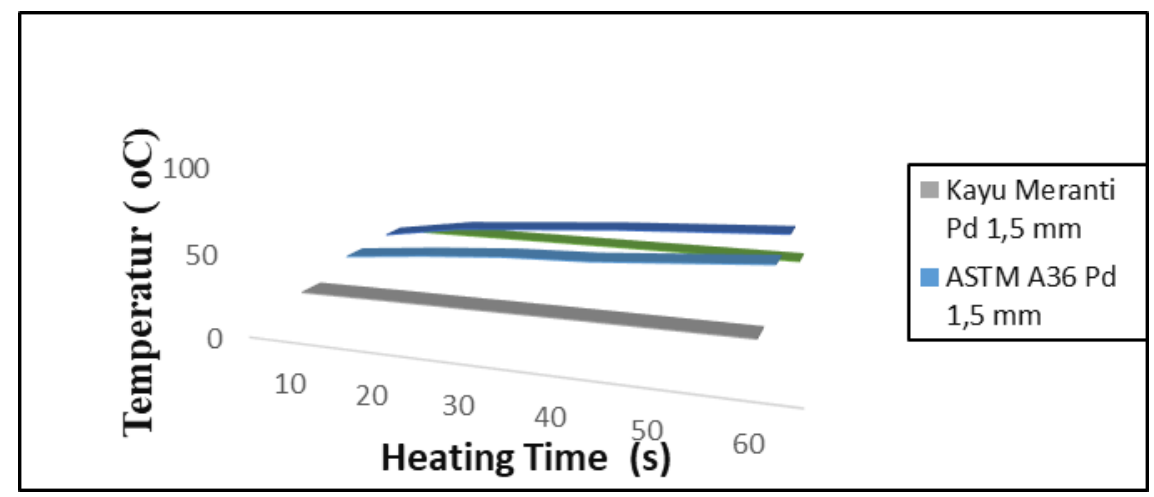

Gambar 7. Temperatur clamping frame

\subsection{Analisis Variasi Heating Time}

Analisis variasi dari heating time ditunjukkan pada Gambar 8, dimana memperlihatkan perbedaan dimensi antar variasi heating time.

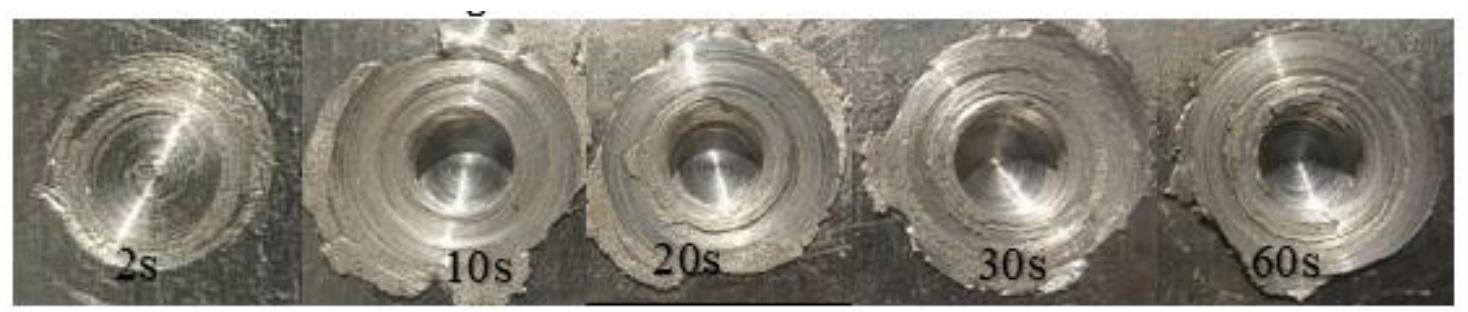

Gambar 8: Diameter lasan di tiap waktu pemanasan

Gambar 8 menjelaskan tentang daerah yang terkena gesekan oleh pin dan shoulder dari tool sehingga menghasilkan kalor dan terjadilah proses pelunakan pada PVC yang akan menempel dan menghasilkan mechanical interlocking sehingga menyatu dengan Alumunium.

Dari Gambar dapat dilihat pada detik ke 2 proses pengelasan belum terjadi secara sempurna, terlihat masih belum terbentuk lubang dengan kedalaman tertentu, disini temperatur yang terukur sangatlah tinggi dalam waktu singkat, hal ini dikenal dengan temperatut jump, fenomenanya dapat dilihat di Gambar 4.1 pada detik 0 menuju detik 2, penyebabnya adalah tool masih melakukan gerakan vertikal untuk menembus alumunium untuk membentuk lubang yang mana pergerakan tersebut juga sekaligus memindahkan massa pada daerah yang akan dilubangi, disana masih sangat banyak alumunium yang bisa terkena gesekan pada suatu daerah lasan sehingga pada detik 0 menuju detik 2 terjadilah peningkatan temperatur yang paling tinggi dalam proses pengelasan friction stir spot welding ini.

Pada Gambar 8 grafik temperatur menurun dimulai detik 2 sampai detik 60, semakin lama heating time berlangsung, semakin pula banyak massa alumunium pada daerah lasan yang terpindahkan, pada Gambar 4.6 dapat dibandingkan daerah lasan yang terbentuk ditiap waktu pemanasan, terlihat daerah yang ter-las semakin lama semakin banyak, semakin lama waktu pemanasan semakin sedikit pula alumunium yang dapat digesek untuk menghasilkan panas, karena massa alumunium sudah banyak yang dipindahkan.

\subsection{Analisis SEM (Scanning Electron Microscope) Pada PVC}

Analisis SEM dari PVC ditunjukkan pada Gambar 9 dan Gambar 10, dimana memperlihatkan ada atau tidak adanya teeth imprint 


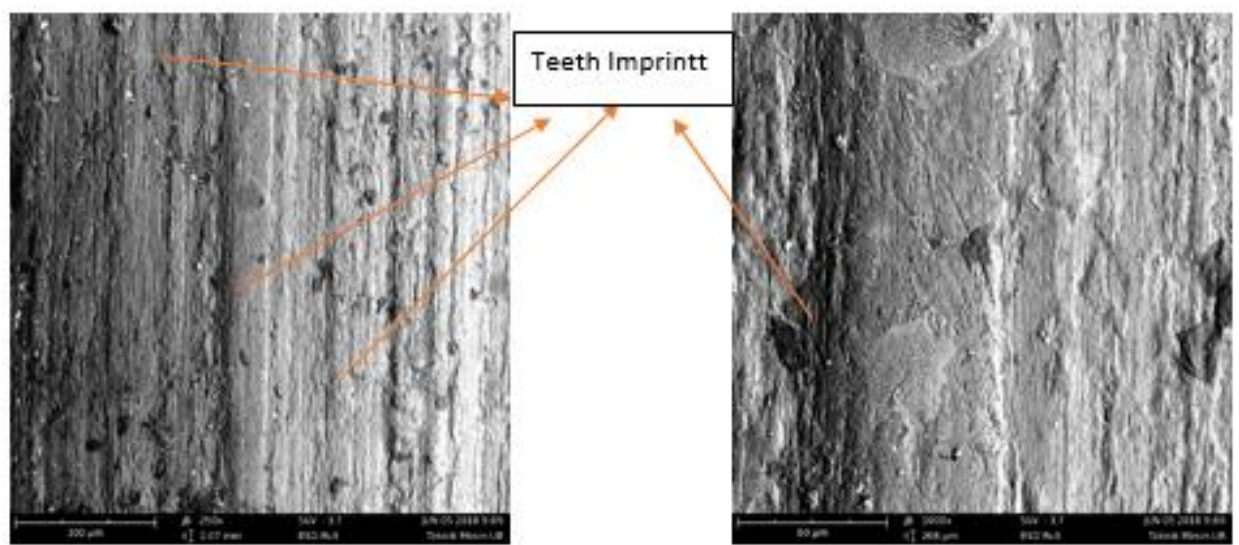

(a)

(b)

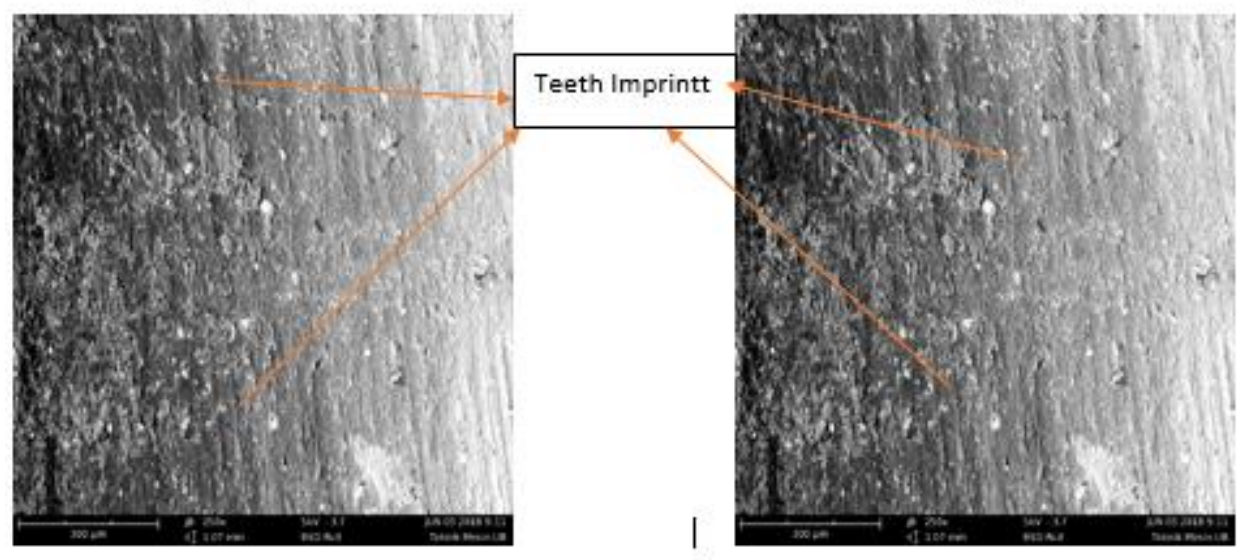

(c)

(d)

Gambar 9: Hasil analisis foto SEM morfologi PVC diatas dengan perbesaran 250x.

Gambar 9 dan 10 merupakan hasil analisis foto SEM morfologi PVC diatas dengan perbesaran 250x dan 1000x, pada Gambar 9a dan 9b, adalah hasil foto SEM menggunakan PVC dengan heating time 10 detik, sedangkan Gambar 9c dan 9d, adalah hasil foto SEM dengan heating time 20 detik. Gambar 10a dan 10b, adalah hasil foto SEM menggunakan PVC dengan heating time 30 detik, sedangkan $10 \mathrm{c}$ dan $10 \mathrm{~d}$ adalah foto SEM untuk PVC dengan heating time 60 detik.

Pada Gambar 9a dan 9b dapat dilihat teeth imprint masih terlihat jelas, hal ini dikarenakan oleh PVC yang belum menerima degradasi termal karena panas yang masuk belum berlebih. Pada Gambar 9c dan 9d, teeth imprint terlihat lebih kecil serta muncul daerah yang lebih gelap dari Gambar 9a dan 9b, hal ini menunjukan bahwa panas yang masuk ke PVC semakin banyak sehingga dapat menghasilkan daerah joining yang lebih banyak, hal ini akan memberikan kekuatan geser yang lebih tinggi, selain itu, teeth imprint yang lebih kecil juga bisa menurunkan kekuatan geser, namun dari data pengujian, spesimen dengan heating time 20 detik memiliki kekuatan geser yang lebih tinggi dibandingkan dengan heating time 10 detik, hal ini mengindikasikan bahwa pada penelitian ini degradasi termal yang terjadi pada heating time 20 detik masih belum cukup untuk membuat kekuatan geser berkurang.

Pada Gambar 10a,b dan 10c,d, teeth imprint sudah tidak terlihat jelas, semakin lama heating time membuat semakin tidak terlihatnya teeth imprint, begitupula dengan daerah yang berwarna gelap semakin banyak seiring dengan bertambahnya heating time. Pada penelitian ini pula kekuatan geser pada detik 30 dan detik 60 menurun, hal ini membuktikan bahwa struktur PVC sudah mengalami degradasi termal yang banyak yang akan menurunkan kekuatan geser dari joint. 


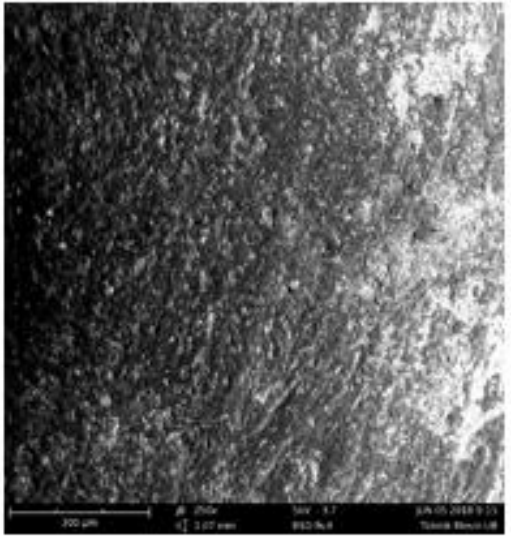

(a)

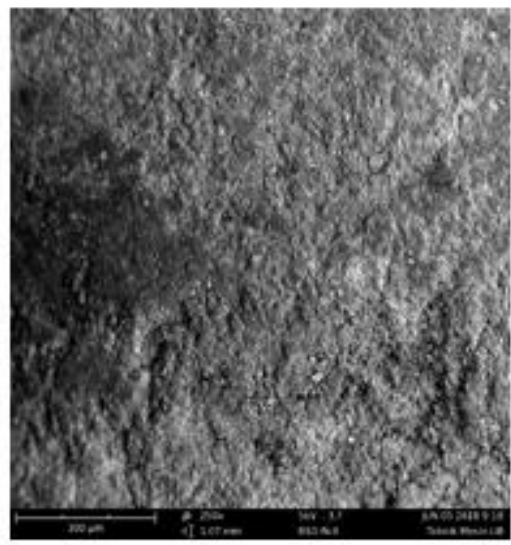

(c)

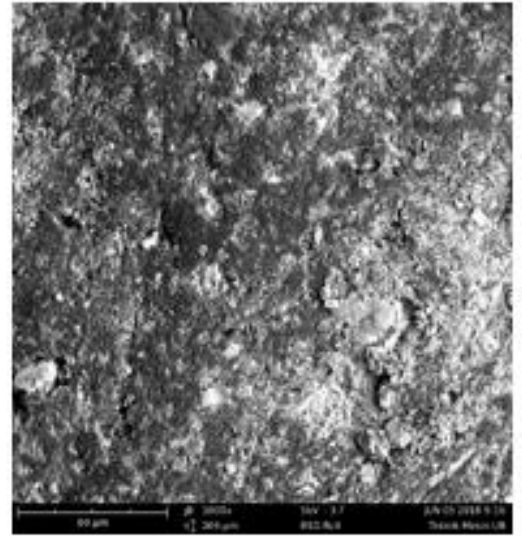

(b)

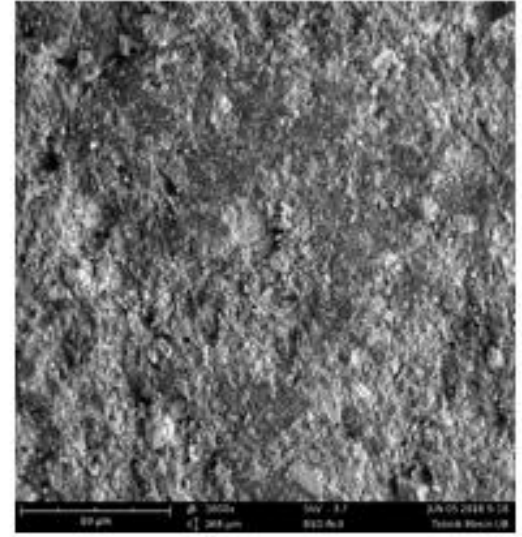

(d)

Gambar 10: Hasil analisis foto SEM morfologi PVC diatas dengan perbesaran 1000x

\section{KESIMPULAN}

Berdasarkan penelitian yang telah dilaksanakan makan dapat disimpulkan bahwa Clamping frame berpengaruh pada kekuatan geser dari sambungan antara Alumunium dan PVC, dimana tiap clamping frame memiliki nilai konduktivitas thermal tersendiri dimana hal ini berpengaruh pada banyaknya kalor yang terkonduksi dari alumunium ke material clamping frame, dengan clamping frame yang memiliki nilai konduktivitas thermal rendah akan menghasilkan temperatur pada spesimen yang lebih tinggi, hal ini mempercepat terjadinya degradasi thermal pada PVC yang menyebabkan terjadinya perubahan kekuatan geser spesimen. Plunge depth mempengaruhi kekuatan geser pada sambungan antara Alumunium dengan PVC, plunge depth berpengaruh pada pembentukan nub, kedalaman nub yang terbentuk akan dapat meningkatkan kekuatan geser karena $n u b$ berperan dalam menahan beban geser.

\section{DAFTAR PUSTAKA}

[1] A. BANDYOPADHYAY, S. BOSE. Additive Manufacturing. CRC Press, Florida, 2015.

[2] TD WIDODO, R RAHARJO, H KUSUMANINGSIH, R BINTARTO, RC SISWOYO. "Pengaruh Tegangan dan Waktu pada Proses Elektropolishing terhadap Surface Roghness Material Stainless Steel AISI 316L”, Rekayasa Mesin 10 (3), 309-316, 2020.

[3] C.K. CHUA, K.F. LEONG. 3D Printing and Additive Manufacturing: Principles and Applications, World Scientific Publishing Company, Singapore, 2017.

[4] LI, SICHUANG XUE, PATRICK PRICE, XING SUN, JIE DING, ZHONGXIA SHANG, ZHE FAN, HAN WANG, YIFAN ZHANG, YOUXING CHEN, HAIYAN WANG, KHALID HATTAR, XINGHANG ZHANG. "Hierarchical nano twins in single-crystal-like nickel with high strength and corrosion resistance produced via a hybrid technique". Nanoscale; 12 (3): 1356, 2020.

[5] BERND R. BURCHARDT, dan PETER W. MERZ. "Elastic Bonding and Sealing in Industry", Hand- 
book of Adhesives and Sealants Volume 2, Pages 355-480, 2006.

[6] JIRI GEORGE DROBNY. "Thermoplastic Elastomers Based on Polyamides", Handbook of Thermoplastic Elastomers (Second Edition) Plastics Design Library, Pages 255-269, 2014.

[7] COWIE, J. \& MCKENZIE, G., Polymers: chemistry and physics of modern materials. Glasgow: Blackie, 1991.

[8] FAKIH. M.A. \& SAMIR, M. Friction Stir Welding in Plate Zone. Lebanon: American University of Beirut, 2016.

[9] R. HAZIMEH, R. OTHMAN, K. KHALIL, and G. CHALLITA, "Influence of plies orientations on the stress distribution in adhesively bonded laminate composite joints subjected to impact loadings," Composite Structures, vol. 152, pp. 654-664, 2016.

[10] GOUSHEGIR S.M. Friction Spot Joining of aluminium AA2024/carbon-fibre-reinforced poly (phenylene sulfide) composite single-lap joint. Hamburg: Mater, 2014.

[11] HARSONO., WIRYOSUMARTO, \& OKUMURA, T, Teknologi Pengelasan Logam. Jakarta : Pradnya Paramita, 1994.

[12] HAQUE, R. \& DURANDET, Y. "Investigation of self-pierce riveting (SPR) process data and specific joining events". Journal of Manufacturing Processes, Vol. 30, pp. 148-160, 2017.

[13] KATAYAMA, S., KAWAHITO, Y. \& ARAI, S. Effect of Surface Modification on Laser Direct Joining of Cyclic Olefin Polymer and Stainless Steel. Japan: Joining and Welding Research Institute (JWRI), Osaka University, 11-1 Mihogaoka, Ibaraki, Osaka 567-0047, 2014.

[14] KO, D. \& LAMBIASE, F. Two Steps Clinching of Alumunium and Carbon Fiber Reinforced Polymer Sheets. South Korea: Graduate School of Convergence Science, Pusan National University, Busan 46241, 2016.

[15] R BINTARTO, TD WIDODO, R RAHARJO, MS MA'ARIF, FGU DEWI, dan GD PRATAMA, "Analisa Struktur Mikro dan Kekuatan Bending Sambungan Las TIG dengan Perbedaan Kuat Arus Listrik pada Logam Tak Sejenis Aluminium Paduan 5052-Baja Galvanis dengan Filler Al-Si 4043”, Rekayasa Mesin 11 (1), 125-131, 2020.

[16] AMERICAN SOCIETY FOR TESTING AND MATERIALS (ASTM). Standard Specification for Carbon Steel Structural Steel. United States, 2014.

[17] MATERIALS (ASTM) D3163-01. Standard Test Method for Determining Strength of adhesively bonded rigid plastic lap shear joint in shear tension loading. United States, 2002. 